\section{KAJIAN HUKUM TINDAK PIDANA POLITIK DARI ASPEK HAK ASASI MANUSIA MENURUT PASAL 23 UNDANG-UNDANG NO. 39 TAHUN 1999 DAN PERAN AMNESTI INTERNASIONAL ${ }^{1}$} Oleh : Ronal Wishky Aryono Sitompul ${ }^{2}$ Ruddy R. Watulingas ${ }^{3}$ Nike K. Rumokoy ${ }^{4}$

\begin{abstract}
ABSTRAK
Tujuan dilakukannya penelitian ini adalah untuk mengetahui bagaimana tindak pidana politik dipandang dari aspek HAM menurut Pasal 23 Undang-undang Nomor 39 Tahun 1999 dan bagaimana peran amnesti Internasional terhadap tindak pidana politik. Dengan menggunakan metode penelitian yuridis normatif, disimpulkan: 1 . Tindak pidana politik atau kejahatan politik dengan diberlakukannya Undang-undang Nomor 39 Tahun 1999 tentang Hak Asasi Manusia khususnya Pasal 23 maka pengertian tindak pidana politik diperluas menjadi pelanggaran Hak Asasi manusia sepanjang adanya pembatasan hak-hak politik. 2. Peran Amnesti Internasional sebagai Lembaga Sosial Masyarakat Internasional adalah mengadvokasi hukum kepada masyarakat ataupun organisasi yang ada dalam masyarakat dalam memperjuangkan Hak Asasi Manusia termasuk Hak-hak politik warga negara. Kehadiran Amnesty Internasional di dunia termasuk di Indonesia adalah merupakan partisipasi masyarakat untuk membela Hak Asasi Manusia termasuk hak-hak politik warga negara.
\end{abstract}

Kata kunci: Kajian Hukum, Tindak Pidana Politik, Hak Asasi Manusia, Peran Amnesty Internasional

\section{PENDAHULUAN}

\section{A. Latar Belakang}

Setiap orang bebas untuk memilih dan mempunyai keyakinan politiknya telah diatur dalam Undang-Undang Nomor 39 Tahun 1999 tentang Hak Asasi Manusia di dalam Pasal 23. Indonesia telah meratifikasi Kovenan Internasional tentang Hak-hak Sipil dan Politik (Kovenan Hak-hak Sipil dan politik -

\footnotetext{
${ }^{1}$ Artikel Skripsi

2 Mahasiswa pada Fakultas Hukum Unsrat, NIM. 13071101645

${ }^{3}$ Fakultas Hukum Unsrat, Doktor Ilmu Hukum

${ }^{4}$ Fakultas Hukum Unsrat, Magister IImu Hukum
}

International Covenant on Civil and Political Rights), yang pada Pasal 16 serta Pasal 26 Konvensi tersebut menjamin akan persamaan kedudukan di depan hukum (equality before the law). Semua orang berhak atas perlindungan dari hukum serta harus dihindarkan adanya diskriminasi berdasarkan ras, warna kulit, jenis kelamin, bahasa, agama, pandangan politik berbeda, nasional atau asalmuasal kebangsaan, kekayaan, kelahiran atau status yang lain-lainnya. Kemudian setiap orang bebas untuk mempunyai, mengeluarkan dan menyebarluaskan pendapat sesuai hati nuraninya secara lisan dan atau tulisan melalui media cetak maupun elektronik dengan memperhatikan nilai-nilai agama, kesusilaan, ketertiban, kepentingan umum dan keutuhan bangsa. ${ }^{5}$

Hak politik sebagai bagian dari hak asasi manusia telah terpatri secara jelas dan tegas dalam Undang-Undang Dasar Negara Republik Indonesia tahun 1945 dalam Pasal 1 ayat 2, Pasal 2 ayat 1 , Pasal 6 A ayat 1 , Pasal 19 ayat 1 , Pasal $22 \mathrm{C}$ ayat 1 ; di mana perumusan sejumlah pasal tersebut tidak dibenarkan adanya diskriminasi terhadap hak asasi serta negara harus memenuhi segala bentuk hak asasi setiap warga negaranya melalui produk-produk hukumnya, termasuk hak politik warga negara yang diatur dalam Pasal 27 dan Pasal 28 Undang-Undang Dasar 1945.

Dalam International Covenant On Civil And Political Rights (ICCPR) Tahun 1996, berkaitan dengan hak politik warga negara menegaskan dalam persamaan Pasal 25 bahwa: "Setiap warga negara harus mempunyai hak dan kesempatan yang sama untuk tanpa pembedaan dan pembatasan yang tidak wajar untuk berpartisipasi dalam menjalankan segala urusan umum baik secara langsung maupun melalui wakil-wakil yang dipilih secara bebas, selanjutnya untuk memilih dan dipilih pada pemilihan berkala yang bebas dan dengan hak pilih yang sama dan universal serta diadakan melalui pengeluaran suara tertulis dan rahasia yang menjamin para pemilih untuk menyatakan kehendak mereka dengan bebas, dan untuk mendapatkan pelayanan umum dinegaranya sendiri pada umumnya atas dasar persamaan. Ketentuan ini ditujukan untuk menegaskan

\footnotetext{
${ }^{5}$ Pasal 23 ayat (2) Undang undang Nomor 39 Tahun 1999 tentang Hak Asasi Manusia.
} 
bahwa hak politik, memilih dan dipilih merupakan hak asasi manusia, sehingga jika terjadi pembatasan akan hak tersebut dapat dituntut sebagai pelanggaran hak asasi manusia.

Tindak pidana politik senantiasa diidentifikasi sebagai kejahatan yang menimbulkan gangguan terhadap keamanan negara. Gangguan terhadap keamanan negara selalu dikaitkan dengan gangguan terhadap unsur wilayah negara, rakyat dan kedaulatan. Kejahatan yang menimbulkan gangguan terhadap integrasi wilayah dilakukan dalam bentuk "makar" yang berusaha memisahkan bagian wilayah negara dari wilayah negara RI. Gangguan terhadap rakyat terjadi apabila keamanan masyarakat tidak terjamin karena adanya kerusuhan berkepanjangan dan tidak segera teratasi. Gangguan terhadap kedaulatan terjadi jika "simbol kedaulatan negara" memperoleh serangan yang berakibat timbulnya kerusuhan.

Amnesti Internasional sebagai LSM internasional di bidang penegakan pelanggaran hak asasi manusia, ia melakukan perjuangan terhadap pelanggaran HAM yang terjadi di dunia. Hal tersebut merupakan tujuan utama dari amnesty international yang mendasari pergerakan ini lahir hingga sekarang. Pada International Council Meeting (ICM) amnesty international yang dilaksanakan di Roma, Italia pada 11-15 Agustus 2017, dilakukan beberapa poin amandemen pada visi dan misi Al. Di dalam Statue of Amnesty International terkandung visi Amnesty International yaitu untuk menciptakan dunia dimana setiap individu memiliki hak asasi manusia yang tertuang dalam Deklarasi Universal Hak Asasi Manusia dan standar hak asasi manusia internasional lainnya. Sedangkan misi dari Amnesty International sendiri yaitu untuk meneliti dan mengupayakan pengadaan pergerakan untuk memperjuangkan, mencegah dan mengakhiri segala tindakan yang melanggar nilai-nilai kemanusiaan yang didukung dengan pola kerjasama Amnesty International yang bersifat terbuka terhadap seluruh lapisan masyarakat luas seperti pemerintah, kelompok elit politik, perusahaan, bahkan organisasi pemerintah internasional.

Berdasarkan uraian-uraian yang telah disampaikan diatas, maka penulis akhirnya tertarik untuk melakukan penelitian mengenai "Kajian Hukum Tindak Pidana Politik Dari Aspek Hak Asasi Manusia Menurut Pasal 23 Undang-Undang Nomor 39 Tahun 1999 serta Peran Amnesty Internasional". Persoalan inilah yang menjadi pokok utama dalam pembahasan penulis.

\section{B. Perumusan Masalah}

1. Bagaimana tindak pidana politik dipandang dari aspek HAM menurut Pasal 23 Undang-undang Nomor 39 Tahun 1999?

2. Bagaimanakah peran amnesti Internasional terhadap tindak pidana politik?

\section{Metode Penelitian}

Metode penelitian yang digunakan dalam penulisan skripsi ini adalah metode pendekatan yuridis normatif, ${ }^{6}$ dimana penelitian hukum yuridis normatif atau penelitian hukum kepustakaan yaitu penelitian hukum yang dilakukan dengan cara meneliti tulisan pustaka atau data sekunder belaka yang berhubungan dengan judul skripsi.

\section{PEMBAHASAN}

A. Pandangan Tindak Pidana Politik Pasca berlakunya Undang-undang Nomor 39 Tahun 1999 Tentang Hak Asasi Manusia

Berdasarkan Pasal 1 ayat 1 Undang-undang Nomor 39 Tahun 1999 bahwa Hak Asasi Manusia adalah seperangkat hak yang melekat pada hakikat dan keberadaan manusia sebagai makhluk Tuhan Yang Maha Esa dan merupakan anugerah-Nya yang wajib dihormati, dijunjung tinggi, dan dilindungi oleh negara, hukum, pemerintahan dan setiap orang demi kehormatan serta perlindungan harkat dan martabat manusia.

Prinsip pengakuan dan perlindungan terhadap hak asasi manusia, merupakan bagian dari prinsip perlindungan hukum sehingga pemenuhan akan hak asasi manusia harus menjadi pilar utama dalam penyelenggaraan negara, disamping terjaminnya keadilan dan kepastian hukum karena Indonesia sebagai negara hukum sebagaimana tercantum dalam

\footnotetext{
${ }^{6}$ Soerjono Soekanto dan Sri Mamudji, "Penelitian Hukum Normatif Suatu Tinjauan Singkat", Jakarta, Raja Grafindo Persada, hlm.13.
} 
pasal 1 ayat 3 Undang-undang Dasar Tahun 1945 yang pada sisi lain dituntut untuk mengimplementasikan sebuah pandangan sebagai negara hukum yang memiliki karakteristik falsafah hidup luhur bangsa Indonesia yaitu Pancasila.

Pasca diberlakukannya Undang-undang Nomor 39 Tahun 1999 tentang Hak Asasi Manusia, membawa dampak munculnya tuntutan reformasi di segala bidang kehidupan terutama reformasi dibidang hukum, Pemerintah telah menyesuaikan berbagai peraturan perundang-undangan pidana dengan keadaan yang telah berubah sesuai dengan tuntutan dan kebutuhan masyarakat.

Penyesuaian terhadap keadaan yang telah berubah tersebut adalah wajar karena hukum yang dibuat pada suatu waktu tertentu belum tentu cocok untuk waktu yang lain. Hukum dibuat untuk suatu kurun waktu tertentu sesuai dengan kebutuhan hukum pada kurun waktu bersangkutan. Oleh sebab itu dapat dipahami apabila aturan-aturan hukum yang berasal dari masa lalu dalam banyak hal tidak responsif lagi terhadap kebutuhan-kebutuhan masa kini di mana kehidupan masyarakat telah sama sekali berubah, maka perlu dilakukan reformasi hukum.

Hukum yang dimaksud meliputi hukum yang tertulis dan tidak tertulis, dari berbagai bentuk dan tingkatan, yang menurut pandangan sistemik konseptual strategis, adalah bersumber pada UUD 1945 sebagai "konsep dasar sistem pengelolaan kehidupan nasional" yang sekaligus merupakan induk hukum positif yang melandasi pengelolaan segenap bidang kehidupan bangsa Indonesia, yang mewakili dan mencerminkan pandangan hidup bangsa kita."

Pasal 23 Undang-undang Nomor 39 Tahun 1999 Tentang Hak Asasi Manusia mengatur bahwa:

Ayat 1: Setiap orang bebas untuk memilih dan mempunyai keyakinan politiknya.

Ayat 2: Setiap orang bebas untuk mempunyai, mengeluarkan dan menyebarluaskan pendapat sesuai hati nuraninya, secara lisan dan atau tulisan melalui media cetak maupun elektronik dengan memperhatikan nilai-nilai agama, kesusilaan, ketertiban, kepentingan umum dan keutuhan bangsa.
Bahwa dengan diberlakukannya Pasal 23 ini membawa perubahan yang cukup besar terhadap pengertian maupun penerapan hukum terhadap tindak pidana politik, baik yang diatur oleh Undang-undang Subversi maupun yang ada dalam Kitab Undang-undang Hukum Pidana yang mengatur tentang Tindak Pidana Politik. Salah satu tindakan yang diambil dalam rangka menyesuaikan diri dengan keadaan yang telah berubah tersebut, sekaligus sebagai bukti nyata pemerintah dalam usahanya menghapuskan peraturan perundang-undangan peninggalan masa lalu yang tidak sesuai dengan kehidupan negara yang sudah berkembang ke arah yang lebih demokratis, adalah pencabutan UU. No. 11/PNPS/1963 tentang Pemberantasan Kegiatan Subversi. Pencabutan Undang-undang ini dilakukan pada masa pemerintahan Presiden BJ Habibie dan mendapat sambutan positif dari Dewan Perwakilan Rakyat Republik Indonesia. Rancangan Undang-undang tentang Pencabutan Undang-undang Nomor 11/PNPS/1963 Pemberantasan Kegiatan Subversi telah disampaikan oleh Presiden BJ Habibie kepada pimpinan Dewan Perwakilan Rakyat Republik Indonesia dengan Amanat Presiden tanggal 8 Pebruari 1999 Nomor R.08/PU/II/1999.

Dalam rangka mengisi. kekosongan hukum (rechtvacuum) akibat dicabutnya UU No. 11 Tahun 1963, maka Pemerintah mengajukan Rancangan undang-undang tentang Perubahan kitab Undang-undang Hukum Pidana yang Berkaitan dengan Kejahatan terhadap Keamanan Negara kepada Dewan Perwakilan Rakyat Republik Indonesia dengan Amanat Presiden tanggal 8 Pebruari 1999 Nomor R.07/PU/II/1999 untuk dibicarakan dalam sidang Dewan Perwakilan Rakyat guna mendapat persetujuan.

Akhirnya pemerintah mengesahkan kedua Rancangan Undang-undang tersebut menjadi Undang-undang Nomor 26 Tahun 1999 tentang Pencabutan Undang-undang Nomor 11/PNPS/1963 tentang Pemberantasan Kegiatan Subversi dan Undang-undang Nomor 27 Tahun 19991999 Tentang Perubahan kitab Undang-undang Hukum Pidana yang berkaitan dengan Kejahatan terhadap Keamanan Negara. Urgensi atau latar belakang perlunya dilakukan pencabutan terhadap Undang-undang Nomor 
11/PNPS/1963 dapat dilihat dari bagian menimbang dari Undang-undang Nomor 27 Tahun 1999, yaitu sebagai berikut: a) Bahwa hak asasi manusia sebagai anugerah Tuhan Yang Maha Esa, sebagaimana diamanatkan dalam ketetapan MPR Nomor XVII/MPR/1998 tentang Hak Asasi manusia, secara kodrati melekat. pada diri manusia meliputi antara lain hak memperoleh kepastian hukum dan persamaan kedudukan didalam hukum, keadilan dan rasa aman, hak mengeluarkan pendapat, berserikat dan berkumpul serta meningkatkan kesejahteraan masyarakat berdasarkan Pancasila dan Undang-undang dasar 1945. b) Bahwa Penetapan Presiden Nomor 11 Tahun 1963 tentang pemberantasan Kegiatan Subversi yang ditetapkan menjadi undang-undang oleh Undang-undang Nomor 5 Tahun 1969 dinyatakan materinya perlu ditampung atau dijadikan bahan bagi penyusunan undang-undang baru, namun sampai sekarang undang-undang yang baru tersebut belum terbentuk sehingga penerapannya telah menimbulkan ketidakadilan dan keresahan di dalam masyarakat karena tidak sesuai dengan prinsip negara berdasarkan atas hukum yang demokratis dan perlindungan hak asasi manusia. Undang-undang Nomor 26 Tahun 1999 tentang Pencabutan Undang-undang Nomor 11/PNPS/1963 tentang Pemberantasan Kegiatan Subversi dari dua pasal. Pasal 1 mengatur mengenai pencabutan undangundang Nomor 11/PNPS/1963 tentang pemberantasan kegiatan Subversi, sedangkan Pasal 2 mengatur mengenai saat mulai berlakunya undang-undang ini. Adapun mengenai Undang-Undang Nomor 27 Tahun 1999, dari pertimbangan dapat kita lihat betapa pentingnya keberadaan undang-undang ini. Dalam bagian pertimbangan dinyatakan sebagai berikut:

a. Bahwa hak asasi manusia merupakan hak dasar yang secara kodrati melekat pada diri manusia antara lain meliputi hak memperoleh kepastian hukum dan persamaan kedudukan di dalam hukum, hak mengeluarkan pendapat, berserikat dan berkumpul berdasarkan Pancasila dan Undang-undang Dasar 1945.

b. Bahwa Kitab Undang-undang Hukum Pidana terutama yang berkaitan dengan ketentuan mengenai kejahatan terhadap keamanan negara belum memberi landasan hukum yang kuat dalam usaha mempertahankan Negara Kesatuan Republik Indonesia yang berdasarkan Pancasila sebagai dasar negara.

c. Bahwa paham dan ajaran komunisme/Marxisme-Leninisme dalam praktek kehidupan politik dan kenegaraan menjelmakan diri dalam kegiatan yang bertentangan dengan asasasas dan sendi-sendi kehidupan bangsa Indonesia yang ber-Tuhan dan beragama serta telah terbukti membahayakan kelangsungan hidup bangsa Indonesia. Undang-undang Nomor 27 Tahun 1999 terdiri dari Pasal 1, yang berisi menambah 6 (enam) ketentuan baru diantara pasal 107 dan pasal 108 Bab I Buku II Kitab Undang-undang hukum pidana tentang Kejahatan terhadap Keamanan Negara yang dijadikan Pasal 107 a, Pasal 107 b, Pasal 107 c, Pasal 107 d, Pasal 107 c dan Pasal $107 \mathrm{f}$ serta Pasal II yang berisi ketentuan mengenai berlakunya undang-undang ini.

Adanya anggapan bahwa setelah pencabutan tersebut diatas maka muncul pandangan bahwa tindak pidana politik akan hilang dengan sendirinya ketika Pasal 23 Undang-undang Nomor 39 Tahun 1999 diterapkan dengan maksimal, walaupun ada perubahan dalam Rancangan Undang-undang Kitab Undang-undang Hukum Pidana yang saat ini belum juga selesai sehingga mengakibatkan timbulnya kekosongan hukum. Namun didalam praktek dikatakan bahwa jika terjadi kekosongan hukum maka yang diberlakukan adalah pasal delik politik yang ada dalam KUHP dalam hal ini sebatas pasal 107 KUHP.

\section{B. Peran Amnesty Internasional Terhadap Tindak Pidana Politik}

Amnesty International muncul berawal dari ketidaksenanganya seorang pengacara Peter Benenson yang marah atas di penjaranya dua mahasiswa Portugis yang menyuarakan kebebasan. Peter Beneson menuangkan ketidaksenangannya melalui tulisan artikel dalam Koran The Observer. Pada tahun 1961 Peter Beneson membuat "Amnesty '61", ialah sebuah kampanye yang membela dua 
mahasiswa Portugis yang dipenjara karena melakukan tos politik menggunakan gelas anggur. Apa yang dilakukan Peter Beneson mendapat tanggapan yang sangat menakjubkan dari berbagai belahan dunia. Secara tidak langsung melalui artikel yang ditulis oleh Peter Benenson dunia Internasional disadarkan akan solidaritas dalam penegakan HAM. Kejadian ini membuat bukan hanya lahirnya sebuah organisasi internasional namun juga awal dari perubahan sosial dunia (https://www.amnesty.org/en/who-we-are/).

Pada tahun 1963, Amnesty International bergerak dalam penegakan hak asasi manusia dengan membawa misi untuk membebaskan 140 tahanan politik didunia. Nama Amnesty International mulai terdengar akrab di masyarakat dunia sepanjang tahun itu. Bahkan pejabat publik dan banyak pengacara ikut dalam menyuarakan Hak Asasi Manusia atas nama Amnesty International. Lalu pada tahun 1965, Amnesty International mengirimkan berbagai surat untuk para tahanan politik di dunia. Surat ini berisikan dukungan terhadap mereka yang ditahan. Surat yang dikirim oleh Amnesty International merupakan harapan besar bagi tahanan untuk bebas. Ketika mereka bebas dari tahanan, sebagai ungkapan terima kasih merekapun ikut berjuang dalam penegakan HAM bersama Amnesty International.

Dengan banyaknya anggota yang tergabung maka eksistensi Amnesty International makin terdengar dan memunculkan anggapan bahwa Amnesty International merupakan salah satu kelompok individu didunia atau Organisasi Internasional yang penting dalam penegakan hak asasi manusia didunia oleh PBB. Dengan demikian, keberadaan Amnesty International didunia membuat sebuah peran baru bagi aktor diluar negara dimana tidak hanya negara yang bisa ikut turun dalam kehidupan umat manusia dari sisi politik namun juga ada aspek-aspek lain seperti sosial, budaya dan kemanusiaan yang bisa saja luput dan terlupakan oleh negara. Amnesty International yang berperan sebagai NGO mengambil alih isu-isu yang luput dari mata negara. Dengan alasan kemanusiaan, Amnesty International menjadikan hak asasi manusia sebagai alat mereka mewujudkan sebuah dunia yang damai. Pada tahun 1974,
Seán Macbride politikus Irlandia yang merupakan salah satu pendiri dari Amnesty International mendapatkan Penghargaan Nobel Perdamaian. Ini merupakan salah satu langkah yang baik bagi Amnesty International dalam perwujudan perdamaian dunia. Amnesty International terus saja aktif dalam menangani pelanggaran Hak Asasi Manusia didunia. Mereka mengekspos bagaimana suatu pihak melakukan pelanggaran HAM dengan demikian Amnesty International akan mendapatkan dukungan dari publik dan berbalik menekan siapa yang melanggar HAM. Pada tahun 1977, Amnesty International membuahkan hasil yang baik. Ini pertanda bahwa Amnesty International sangatlah aktif dalam melakukan perannya sebagai NGO.

Penghargaan Nobel sebagai pengakuan atas kontribusi terhadap hak asasi manusia global menjadi dasar sekaligus dorongan bagi Amnesty International untuk terus melakukan penegakan Hak Asasi Manusia di Indonesia. Dalam aktivitas keorganisasian Amnesty International memiliki kesekretariatan. Kesekretariatan Amnesty International tersebar di berbagai belahan dunia guna mempermudah peran Amnesty International dalam melakukan pemantauam tentang pelanggaran HAM ataupun membuat sebuah kampanye pembelaan atau penegakan HAM. Kesekretariatan Amnesty International terletak di :

1. Eropa and Asia Tengah : London (Kantor Pusat), Brussels, Moscow, Geneva.

2. Asia \& Pasifik: Hong Kong, Bangkok (dan berencana melakukan pengembangan Amnesty International di India and Nepal)

3. Afrika: Dakar, Nairobi and Johannesburg

4. Amerika: Mexico City, Lima and Washington 5. Timur Tengah \& Afrika Utara: Beirut (https://www.amnesty.org/en/careers/r egional-offices/)

Kesekretariatan pusat Amnesty International memiliki tanggung jawab untuk melakukan sebuah penelitian ataupun laporan atas pelanggaran HAM yang terjadi. Disinilah titik awal dimana Amnesty International bisa bergerak. Dengan adanya penelitian maka tujuan dan sasaran dari sebuah aktivitas Amnesty International bisa terlihat. 
Amnesty International juga menggunakan para ahli hukum agar lebih mudah untuk aktivitas penegakan HAM. Fungsi lain dari kesekretariatan pusat ialah untuk melayani korban pelanggaran HAM selama $24 \mathrm{jam}$. Hal ini karena, kita tidak bisa mengetahui kapan dan siapa yang akan menjadi korban pelanggaran HAM disuatu wilayah.

Amnesty International, juga melakukan berbagai agenda demi tercapainya penegakan HAM dengan cara yang damai. HAM menjadi alasan utama Amnesty International ikut turun dalam sebuah isu, adapun aktivitas Amnesty International dalam beberapa isu terkait HAM selain politik yakni seperti konflik bersenjata, diskriminasi, penahanan paksa, penyiksaan hingga pelanggaran hak seksual dan reproduksi.

Dalam melakukan aktivitas penegakan HAM, Amnesty International harus memperhatikan beberapa hal yang merupakan standar aktivitas mereka. Organisasi ini bukan seperti organisasi lain yang melakukan segala kegiatannya serta merta hanya ingin menunjukan eksistensinya. Amnesty International melakukan aktivitasnya dengan memperhatikan berbagai hal hingga pakar hukum ikut didalamnya. Demi memberikan keadaan yang lebih baik dalam beraktivitas mereka serta tercapainya tujuan bersama, Amnesty International memiliki beberapa strategi yaitu:

1. Reclaiming Freedom, strategi ini memberikan kesempatan bagi seluruh individu di dunia mengerti tentang Hak Asasi Manusia yang dimiliki setiap individu itu sejak lahir. Amnesty International memberikan akses informasi atas apa yang disebut HAM pada dunia.

2. Securing Equal Rights For All, Strategi ini merupakan tahap selanjutnya dari strategi pertama. Setelah seluruh individu mengerti tentang HAM mereka, maka Amnesty International membantu melindungi HAM yang mereka miliki dan melawan siapapun yang melanggar itu.

3. Responding to Crises, Amnesty International berusaha mengambil peran dalam menangani konflik dan krisis di dunia internasional. Hal ini dikarenakan ketika timbulnya krisis atau konflik disuatu wilayah maka ada kemungkinan munculnya korban konflik dan berujung pada penindasan HAM.

4. Ensuring Accountability, Amnesty International bertindak melakukan sebuah perubahan ditingkat nasional, regional atau internasional ketika negara tidak bertanggung jawab atas penegakan HAM dan ketika aktor lain seperti perusahaan asing juga membuat keadaan semakin buruk.

5. Maximizing Our Resources And Engagement, Amnesty International membuat sebuah gerakan yang menghubungkan ribuan individu dalam memperjuangkan HAM. (https://www.amnesty.org/en/latest/ca mpaigns/2016/01/amnesty-goals2016-2019/).

Di Indonesia, Amnesty International Indonesia mengakui bahwa setelah berakhirnya kekuasaan Presiden Soeharto pada tahun 1998, Indonesia telah melakukan serangkaian perubahan dari segi sosial ataupun kenegaraan yang bertujuan untuk melindungi HAM dan memperkuat supremasi hukum yang lebih baik bagi warga negaranya (Amnesty International, 2014).

Mengingat pada sejarah, peristiwa yang paling dikenang dalam penegakan HAM di Indonesia yakni ketika tidak lagi diskriminasi terhadap etnis Tiongkok. Sehingga mereka diberi kesempatan menjadi warga negara Indonesia oleh Presiden Gus Dur saat itu. Sehingga mencerminkan komitmen dan upaya Indonesia untuk mempromosikan HAM pada tingkatan nasional, regional dan internasional.

Dengan riwayat sejarah yang tidak begitu buruk, Amnesty International pada tahun 2014 masih menyerukan penegakan HAM untuk dihormati, dipenuhi dan dilindungi.

Indonesia telah secara eksplisit mengakui kewajiban HAM-nya dengan meratifikasi beberapa traktat HAM internasional:

1. Kovenan Internasional tentang Hak-Hak Sipil dan Politik (International Covenant on Civil and Political Rights, ICCPR) (2006).

2. Kovenan Internasional tentang Hak-Hak Ekonomi, Sosial, dan Budaya (International Covenant on Economic, Social and Cultural Rights, ICESCR) (2006). 
3. Konvensi PBB tentang Penghapusan Segala Bentuk Diskriminasi terhadap Perempuan (UN Convention on the Elimination of All Forms of Discrimination Against Women, CEDAW) (1984).

4. Konvensi PBB tentang Hak Anak (UN Convention on the Rights of the Child, CRC) (1990)

5. Konvensi PBB Menentang Penyiksaan dan segala bentuk Perlakuan atau Hukuman yang Kejam, Tidak Manusiawi, atau Merendahkan (UN Convention against Torture and Other Cruel, Inhuman or Degrading Treatment or Punishment, CAT) (1998)

6. Konvensi Internasional tentang Perlindungan Hak Semua Pekerja Migran dan Anggota Keluarganya (International Convention on the Protection of the Rights of All Migrant Workers and Members of Their Families) (2013) (Amnesty International, 2015).

Seiring berjalannya waktu, Amnesty International terus menerima laporan yang kredibel tentang pelanggaran-pelanggaran HAM di Indonesia. Menurut Amnesty International, Indonesia tidak konsisten dengan kewajiban HAM Indonesia itu sendiri. Adapun pelanggaran HAM yang terjadi dilakukan oleh pasukan keamanan dan pemerintah gagal untuk membuat mereka bertanggungjawab atas apa yang telah mereka lakukan. Misalnya Pembatasan hak-hak berekspresi, dan beragama, serta pemidanaan aktivis politik damai, terutama di Papua dan Maluku juga membuat predikat Indonesia tidak konsisten dalam memenuhi kewajiban HAM mereka.

Dengan demikian pada Tahun 2014 tepatnya menjelang pemilihan pemilu di Indonesia, Amnesty International menyuarakan kepada kandidat presiden untuk memegang komitmen yang kuat dalam menindaklanjuti agenda HAM berikut ini:

1. Menjamin akuntabilitas atas pelanggaran HAM oleh pasukan keamanan

2. Menghormati dan melindungi kebebasan berpikir, berhati nurani dan beragama

3. Menegakkan hak kebebasan berekspresi dan melindungi pembela HAM

4. Mengakhiri impunitas
5. Menegakkan hak perempuan dan anak perempuan

6. Menghormati HAM di Papua

7. Mengakhiri penggunaan hukuman mati

8. Mempromosikan dan melindungi HAM di ASEAN.

Amnesti Internasional dalam peluncuran laporan tahunan mengenai situasi Hak Asasi Manusia pada 159 negara di dunia termasuk Indonesia, yang dirilis pada tanggal 22 Februari tahun 2018 dengan judul: The State of The World's Human Rights; Dalam laporan tersebut disentil mengenai isu "Politik Ujaran Kebencian" yang membawa dampak sosial dan politik berkepanjangan, misalnya kasus mantan Gubernur DKI Jakarta Basuki Tjahya Purnama/Ahok yang divonis dua tahun penjara karena dituduh menista agama. Hal ini dilakukan oleh lawan politik Ahok menggunakan sentimen anti Islam untuk mengumpulkan ratusan ribu massa di Jakarta dan menekan penegak hukum untuk memenjarakan Ahok. Peristiwa ini sangat menggemparkan dunia sehingga banyak negara-negara pemerhati HAM menyatakan prihatin akan peristiwa ini dan tercatat dalam sejarah perjuangan HAM yang cukup menarik perhatian dunia.

Peran Amnesti Internasional dalam mengungkap kasus-kasus politik di Indonesia berjalan dengan baik, Direktur Eksekutif Amnesty Internasional Indonesia Usman Hamid dalam laporan terbaru pada bulan Juli 2018 mencatat bahwa hasil penelitian mereka ternyata ada 95 kematian (penembakan yang dilakukan aparat), dalam 69 insiden antara Januari 2010 sampai Februari 2018 terjadi di Papua dengan perincian 56 terjadi dalam konteks kegiatan non kemerdekaan, sementara 39 lainnya terkait dengan kegiatan politik damai, seperti demonstrasi dan atau menaikkan bendera kemerdekaan Papua Bintang Kejora. Peran Amnesti internasional di tingkat dunia tercatat telah melakukan aksi kampanye yang pada dasarnya adalah aksi dilakukan oleh Amnesti Internasional untuk menekan pemerintah Myanmar untuk menghentikan pelanggaran Hak Asasi Manusia dibidang politik.

Pada tahun 2015 Amnesti Internasional melakukan aksi protes yang kedua kalinya kembali dengan melakukan kampanye karena 
banyak para aktivis yang melakukan aksi damai kemudian dipenjarakan, pembatasan berbicara dan pencabutan hak politik kelompok minoritas, khususnya Rohingya.

Amnesti Internasional juga berhasil melakukan sebuah wawancara dengan mewawancarai para korban, wawancara ini dilakukan dengan tujuan agar ditemukannya pelanggaran pelanggaran HAM yang dilakukan oleh pemerintah Myanmar terhadap etnis Rohingya. Banyak sekali para korban etnis Rohingya yang mengalami sebuah kekerasan dan mereka memilih untuk mengungsi ke beberapa negara tetangga.

Beberapa etnis Rohingya juga menghabiskan waktu di beberapa perahu yang berbeda memberikan kesaksian pada Amnesti Internasional jika mereka melihat awak perahu membunuh penumpang. Seorang pemuda Rohingya berusia 17 tahun dari Nayapara di Bangladesh berkata dia menyaksikan seorang lelaki ditembak dan dibuang ke laut karena keluarganya tidak bisa membayar tebusan dalam kurun waktu sebuah bulan yang ditentukan oleh awak perahu. (Perjalanan Mematikan Krisis Pengungsi dan Perdagangan di Asia Tenggara 2015:20).

Atas kondisi yang memprihatinkan tersebut Amnesti Internasional mempersiapkan sebuah laporan Universal Periodic Review (UPR) pada bulan November 2015 di negara Myanmar. UPR adalah sebuah proses laporan di bawah naungan Dewan Hak Asasi Manusia, untuk mendorong dan memberikan kesempatan bagi setiap negara untuk menyatakan tindakan apa yang telah mereka lakukan untuk memperbaiki situasi Hak Asasi Manusia di negaranya. UPR adalah salah satu elemen kunci dari Dewan Hak Asasi Manusia yang mengingatkan negara tentang tanggung jawab mereka untuk sepenuhnya menghormati dan melaksanakan semua Hak Asasi Manusia dan kebebasan dasar. Tujuan nya adalah untuk memperbaiki situasi Hak Asasi Manusia di semua negara dan menghentikan masalah pelanggaran Hak Asasi Manusia.

\section{PENUTUP}

\section{A. Kesimpulan}

1. Tindak pidana politik atau kejahatan politik merupakan kata majemuk yakni "kejahatan" dan "politik". Pengertian
Kejahatan dalam Kitab Undang-undang Hukum Pidana membedakan dari sudut pandang yuridis dan sosiologis. Dari sudut pandang yuridis kejahatan adalah suatu perbuatan tingkah laku yang bertentangan dengan undang-undang. Sedangkan dari sudut pandang sosiologis kejahatan adalah perbuatan atau tingkah laku yang selain merugikan si penderita, juga sangat merugikan atau berupa hilangnya keseimbangan, ketentraman dan ketertiban. (R. Soesilo). Sedangkan pengertian politik menurut Miriam Budiardjo bahwa politik merupakan bermacam kegiatan dalam suatu sistem politik yang menyangkut proses menentukan tujuan dari sistem tersebut dan cara mencapai tujuan tersebut. Dengan pengertian politik adalah segala urusan yang menyangkut negara atau pemerintahan melalui suatu sistem politik yang menyangkut tujuan dari sistem tersebut. Jadi kejahatan/tindak pidana politik adalah kejahatan yang berhubungan dengan berfungsinya negara dan atau pemerintahan.

Namun dengan diberlakukannya Undangundang Nomor 39 Tahun 1999 tentang Hak Asasi Manusia khususnya Pasal 23 maka pengertian tindak pidana politik diperluas menjadi pelanggaran Hak Asasi manusia sepanjang adanya pembatasan hak-hak politik.

2. Peran Amnesti Internasional sebagai Lembaga Sosial Masyarakat Internasional adalah mengadvokasi hukum kepada masyarakat ataupun organisasi yang ada dalam masyarakat dalam memperjuangkan Hak Asasi Manusia termasuk Hak-hak politik warga negara.

Kehadiran Amnesty Internasional di dunia termasuk di Indonesia adalah merupakan partisipasi masyarakat untuk membela Hak Asasi Manusia termasuk hak-hak politik warga negara.

\section{B. Saran}

1. Diperlukan adanya rumusan yang jelas tentang tindak pidana politik atau kejahatan politik dalam perundangundangan dengan maksud agar tidak 
terjadi multi tafsir tentang tindak pidana politik demi kepastian hukum.

2. Amnesti Internasional Indonesia agar lebih disosialisasikan kepada masyarakat umum untuk mempercepat kesadaran hukum masyarakat dalam menghargai hak asasi manusia termasuk hak-hak politik warga negara.

\section{DAFTAR PUSTAKA}

Buku

A.B. Loebis, "Kejahatan Politik Di Indonesia" Rajawali Pers Tahun 1999

Adam Podgorecki \& Chritopher J Whelan, Pendekatan Sosiologis Terhadap Hukum, PT. Bina Aksara Jakarta, Tahun 1987

Aloysius, R. Entah, "Indonesia Negara Hukum Yang Berdasarkan Pancasila", Jurnal Hukum Fakultas Hukum Universitas Negeri Semarang, Thn. 2010

Barda Nawawi Arief, Bunga Rampai Kebijakan Hukum Pidana, E-Journal Undip

Tahun 2016.

Barda Nawawi Arief, "Perbandingan Hukum Pidana" , Raja Grafindo Persada, Jakarta Tahun 2002

Loebby Loqman, "Delik Politik Di Indonesia", Jakarta. Ind. Hill.Co, Tahun 1999.

"Kebijakan Kriminal Dalam Rangka Menanggulangi Kejahatan Politik" Makalah disampaikan pada Seminar Nasional Hukum Pidana, di Fakultas Hukum Undip Semarang, Tahun 1999.

R.M. Thalib Purjokusumo, Kebijakan Kriminal Dalam Menanggulangi Kejahatan Politik" , Jurnal Fakultas Undip Semarang Tahun 2019.

R. Soesilo, Kitab Undang-undang Hukum Pidana Beserta Penjelasannya.

Rio Amanda Agustian, "Tindak Pidana Terhadap Keamanan Negara Dalam Perspektif Delik Politik Di Indonesia", Jurnal Masalah-masalah Hukum Tahun 2011.

Soerjono Soekanto dan Sri Mamudji, Penelitian Hukum Normatif Suatu Tinjauan Singkat, Raja Grafindo persada Jakarta, Tahun 2001.

\section{Peraturan Perundang-Undangan}

Undang-undang Dasar Negara Republoik Indonesia 1945 Dan Amandemennya.

Undang-undang Nomor 39 Tahun 1999 Tentang Hak Asasi Manusia

\section{Website}

http://infohukum.com/2009/04/20

http://id.wikipedia

http://www.amnesty.org 